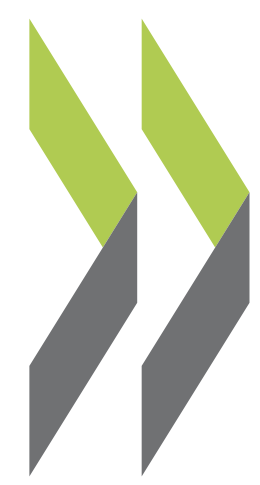

OECD Regional Development Working Papers 2015/02

\title{
Municipal Fragmentation and Economic Performance of OECD TL2 Regions
}

\section{David Bartolini}




\section{OECD REGIONAL DEVELOPMENT WORKING PAPERS}

This series is designed to make available to a wider readership selected studies on regional development issues prepared for use within the OECD. Authorship is usually collective, but principal authors are named. The papers are generally available only in their original language English or French with a summary in the other if available.

OECD Working Papers should not be reported as representing the official views of the OECD or of its member countries. The opinions expressed and arguments employed are those of the author(s).

The statistical data for Israel are supplied by and under the responsibility of the relevant Israeli authorities. The use of such data by the OECD is without prejudice to the status of the Golan Heights, East Jerusalem and Israeli settlements in the West Bank under the terms of international law.

Working Papers describe preliminary results or research in progress by the author(s) and are published to stimulate discussion on a broad range of issues on which the OECD works. Comments on Working Papers are welcomed, and may be sent to either gov.contact@oecd.org or the Public Governance and Territorial Development Directorate, OECD, 2 rue André-Pascal, 75775 Paris Cedex 16, France.

Authorised for publication by Rolf Alter, Director, Public Governance and Territorial Development Directorate, OECD.

OECD Regional Development Working Papers are published on http://www.oecd.org/gov/regional/workingpapers

Applications for permission to reproduce or translate all or part of this material should be made to: OECD Publishing, rights@oecd.org or by fax 33145249930.

(C) OECD 2015 


\title{
MUNICIPAL FRAGMENTATION AND ECONOMIC PERFORMANCE OF OECD TL2 REGIONS $^{1}$
}

\author{
by David Bartolini
}

\begin{abstract}
The present work investigates the relationship between municipal fragmentation and regional per capita GDP growth rate, using a panel of OECD TL2 regions in the period 1996-2011. According to the fiscal decentralisation literature, fragmentation should enhance growth as local government closer to citizens can implement policies that better match their needs, thus providing services and public goods in a more efficient way. The presence of many local governments, however, may create problems in terms of overlapping functions, (dis)economies of scale, and policy fragmentation.

The results of the empirical analysis show that municipal fragmentation has a negative impact on per capita GDP growth, thus supporting the view that costs prevail on benefits. The introduction of regional territorial characteristic - namely, the share of population living in rural areas - provides a different picture, however. The negative impact of fragmentation decreases with the share of population living in rural areas. Indeed, in extremely "rural" regions the effect turns mildly positive. This is because the costs and benefits of fragmentation have a different weight in urban and rural regions. The key insight is the different distribution of the population over the territory: more concentrated in urban than in rural regions. This implies that, for a given level of municipal fragmentation overlapping of function is more severe in urban regions (where people are likely to commute over municipal boundaries) than in rural area. In the same vein, for the same level of municipal fragmentation access to the local government is more difficult in rural areas (where people is sparsely located within municipal boundaries) than in urban areas.

The policy implications of the analysis are twofold. Firstly, reducing municipal fragmentation may have a heterogeneous impact within the country, thus raising concern for one-size-fits-all policies of municipal agglomeration in favour of a place-based approach to institutional reform. For instance, the principle guiding municipal amalgamation should not be the average municipal size at the country level, but it should be weighted for the rural/urban characteristics of each region. Secondly, the analysis suggests that processes of agglomeration of people should be accompanied by a consistent amalgamation of the local administration, otherwise representing an obstacle to the full realisation of agglomeration economies.
\end{abstract}

Keywords: Regional growth, Institutions, Local governments

JEL Classification: R11, R50

1. I would like to thank for very useful comments Luiz de Mello, Joaquim Oliveira Martins, Enrique Garcilazo, Raffaele Trapasso, Alexander Lembcke, Abel Schumann, Isabelle Chatry, and all participants to GOV/RDP seminars. The ideas and opinions expressed in this paper are sole responsibility of the author and do not reflect the position of the OECD or any of its member countries. 


\section{TABLE OF CONTENTS}

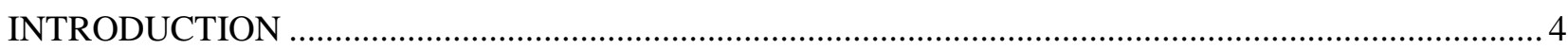

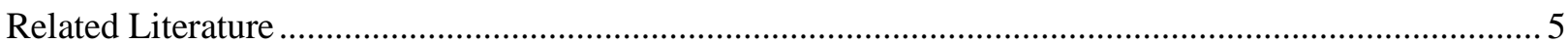

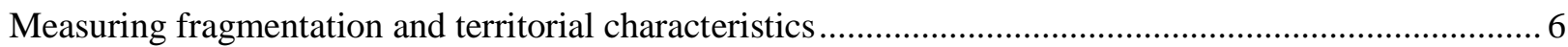

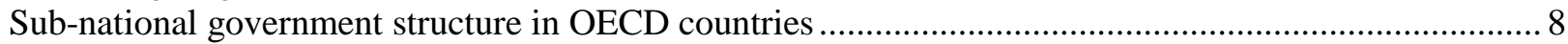

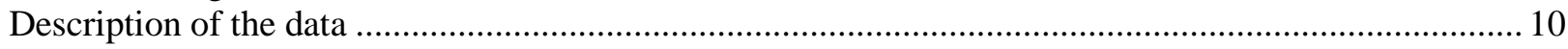

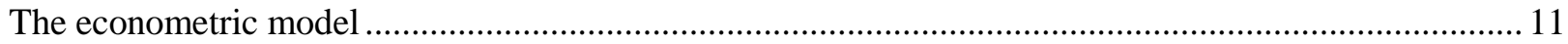

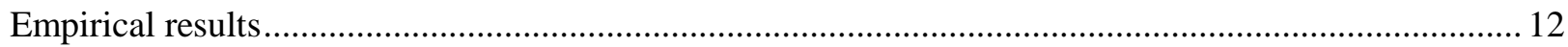

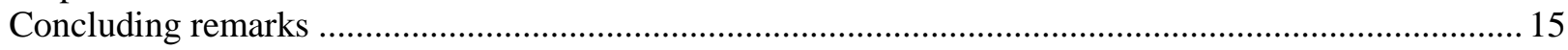

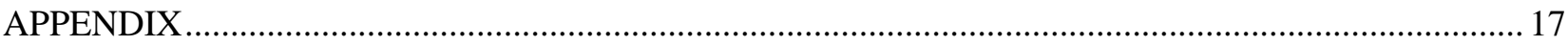

A1. Impact of municipal fragmentation in OECD countries ................................................................ 17

A2. Administrative territorial reforms may result in asymmetries between urban and rural areas ........... 18

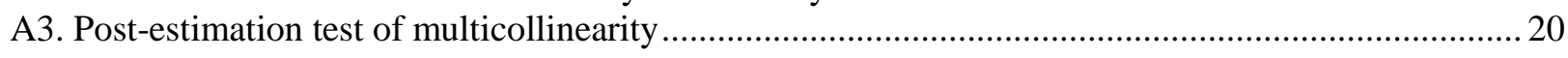

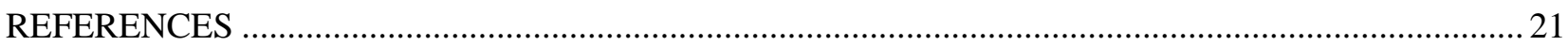

\section{Tables}

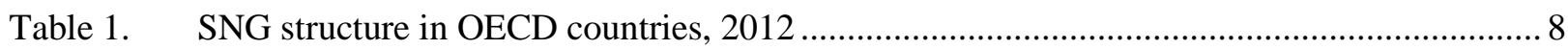

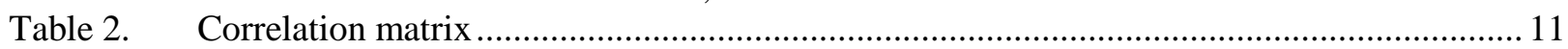

Table 3. Estimation results of the impact of horizontal fragmentation on regional TL2 economic growth..... 12

Table 4. Impact of fragmentation on per-capita GDP growth, by country ...................................... 17

Table 5. Examples of recent territorial and administrative reform in OECD countries ...................... 19

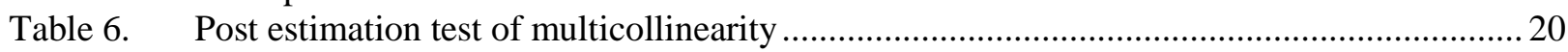

\section{Figures}

Figure 1. Municipal fragmentation in OECD countries ................................................................... 10

Figure 2. Impact of fragmentation of GDP graph - post regression diagnostic................................. 14

Figure 3. Estimated effect of institutional fragmentation on annual per-capita GDP growth, in

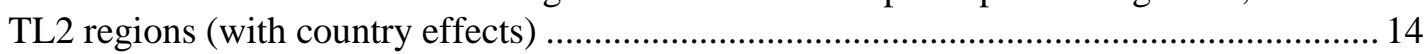

Figure 4. Share of TL2 units gaining from reduction of fragmentation .......................................... 15 


\section{Introduction}

The governance structure of a country has important consequences for its economic performance. Along with the "traditional" factors of production - labour, capital and technology -institutions have received increasing attention as drivers of economic growth (Williamson, 1975; North, 1990; Acemoglu and Robinson, 2006). A well-functioning public administration provides policies and regulations that are essential to create a sound business environment. An important component of governance is the territorial structure of the public administration. How many local governments should be created in a given territory? What should their functions be? Is one-size-fits-all an appropriate model? The present work deals with some of these questions by considering the partition of population into local governments. To this end an indicator of municipal fragmentation is constructed for 250 OECD TL2 regions, and its relationship with the per capita regional GDP growth is tested empirically.

Municipal fragmentation is measured as the number of municipalities per 100,000 inhabitants within each OECD TL2 region. This indicator captures the size of local governments with respect to the population served, thus neutralising any bias introduced by regional size. Municipal fragmentation is evaluated on the basis of its impact on the annual growth rate of regional per capita GDP, in the period 1996-2011.

The structure of the local administration affects economic performance mainly through the provision of local public goods and the attraction of people and businesses in the territory. Previous studies have mainly focused on metropolitan areas, investigating the role of fragmentation in the provision of public goods for the whole metropolitan area (for instance, transport and housing policies). Indeed, one of the main problems with municipal fragmentation is the need to co-ordinate policies that have an impact beyond the local government's boundaries (policy spillovers). Nelson and Foster (1999), for instance, find that municipal fragmentation reduces income per capita in US large metropolitan areas; a recent OECD work finds a negative relationship of municipal fragmentation with productivity of large metropolitan areas (OECD, 2015).

The impact of municipal fragmentation, however, may differ according to the type of territory considered. Stansel (2005) finds a positive relationship between horizontal fragmentation and per capita income growth when including metropolitan areas of all sizes in the analysis. This is probably due to the different weight that drawbacks of fragmentation have in less densely populated areas. In particular, when the population is scattered over a vast territory there is less commuting over municipal boundaries, thus reducing the problem of policy spillovers and the need of (costly) cooperation. Therefore, the same level of municipal fragmentation may have a different economic impact in urban and rural regions.

Investigating the impact of municipal fragmentation distinguishing between urban and rural regions is the main contribution of this paper. To this end, an indicator of population concentration within the regional boundaries is constructed, by taking into account the share of regional population living in rural areas (rural index). ${ }^{2}$ This indicator is a discrete measure of the level of urbanisation of each region, thus allowing to test the hypothesis that fragmentation hinders economic growth the more urban is the territory.

The empirical investigation is conducted on a cross-section of 250 TL2 OECD regions, covering 23 OECD countries. Results show that municipal fragmentation has a negative impact on the annual growth rate of real per-capita GDP, averaged over the period 1996-2011. GDP growth is also negatively affected by the share of population living in rural areas, that is, rural regions tend to growth less than urban ones. However, the interaction between fragmentation and the rural index confirms the hypothesis of a negative impact in urban regions. In particular, the lower the rural index the higher the negative impact of fragmentation.

2. This measure is correlated to population density, but avoids the risk of having low densely populated regions although most of the population concentrates in few areas. 
The analysis confirms that urban regions benefit from a reduction of municipal fragmentation, whereas rural regions are not affected or may even benefit from fragmentation. The economic intuition for the latter result rests on the benefits of municipal fragmentation in terms of better match with citizens' preferences and better (and easier) access to local politicians - this is also important in terms of the "voice" of rural community towards the higher levels of government (Hirschman, 1970). In rural areas, decreasing municipal fragmentation means that local governments would manage an even vaster area, increasing the difficulty to reach citizens and match their preferences. To summarise, the empirical analysis confirms that a given level of municipal fragmentation has a different impact on the economic growth of urban and rural regions. The drawbacks of fragmentation that hinder economic growth in urban regions are counterbalanced by the benefit of closer relationship with citizens in rural regions.

The policy implications of the analysis are twofold. Firstly, reducing municipal fragmentation may have a heterogeneous impact within the country, thus raising concern for one-size-fits-all policies of municipal agglomeration in favour of a place-based approach to institutional reform. For instance, the principle guiding municipal amalgamation should not be the average municipal size at the country level, but it should be weighted for the rural/urban characteristics of each region. Secondly, the analysis suggests that processes of agglomeration of people should be accompanied by a consistent amalgamation of the local administration, otherwise representing an obstacle to the full realisation of agglomeration economies.

The rest of the paper is organised as follows. The next section provides a review of the literature on horizontal fragmentation and economic growth. Then, a brief discussion of the measures of fragmentation and a snapshot of current administrative structures in OECD countries are provided. The paper continues with the description of the data and the econometric model. Results of the empirical analysis are presented, along with a discussion of policy implications. A final section concludes with a summary of the main results and suggestions for further work.

\section{Related Literature}

The impact of administrative fragmentation on economic growth depends on the value given to regional competition and to the closer relationship with citizens. Accordingly, it is possible to gather most of the arguments in two main theories: a polycentric; and a centrist model (Nestor and Foster, 1999). The polycentric view tends to stress the positive impact of competition between local governments for the efficient provision of public services, and the possibility to benchmark the behaviour of local administrators with their neighbours (electoral yardstick competition, see Bartolini and Santolini, 2012); furthermore, a fragmented territorial administration offers a wider choice of service and tax bundles to firms and residents (Tiebout, 1956). The public choice literature can also be considered polycentric, given the importance of "taming" the Leviathan through a proliferation of competing administrative bodies (Brennan and Buchanan, 1980). By contrast, the centrist view stresses the drawbacks of competition in terms of "race to the bottom" for the attraction of the tax base, the emergence of dis-economies of scale in the provision of local public goods, and the presence of policy spillovers that would require costly co-operation among local governments (Hamilton et al, 2004). (Hamilton D. and Miller D. and J. Paytas (2004) "exploring the horizontal and vertical dimensions of the governing of metropolitan regions" in Urban affairs review, 40(2), pp. 147-182) From this brief overview of the main literature, it appears that the actual impact of horizontal fragmentation on economic growth depends on the size of these contrasting effects in specific contexts, and thus remains an empirical question.

The empirical literature has mainly focused on US metropolitan areas. ${ }^{3}$ Some works back the centrist view, finding empirical evidence for the drag of horizontal fragmentation on economic growth. For instance, both Nelson and Foster (1999), and Paytas (2001) investigate income growth in

3. This literature review draws on Wolman H, Levy A, and Hincapie D (2011) "Government, Governance, and Regional Economic growth" working paper 044, George Washington Institute of Public Policy, Washington, DC. 
US metropolitan areas, showing that administrative fragmentation reduces income per capita. More recently, Ahrend et al (2014) show that municipal fragmentation reduces the "premium" of large metropolitan areas in terms of higher wages. There are, however, a few works baking the polycentric view. Randall and Gronberg (1990) focus on the number of local governments and the impact on the size of government spending, showing that fragmentation tends to increase local spending, attracting more firms and people in the area, and thus positively contributing to economic growth. Stansel (2005) finds a positive impact of horizontal fragmentation and economic growth. His study covers 314 US metropolitan areas, focusing on the number of municipalities per 100,000 residents, and the number of counties per 100,000 residents.

The apparent contrast between these set of empirical works can partly be attributed to the indicator of fragmentation used and to the extent of the territory considered. As regards the type of indicator, Grassmueck and Shield (2010) criticise the use of the number of municipalities as an indicator of administrative fragmentation as it masks the different role played by municipalities with different powers. To overcome this shortcoming they consider an index which takes into account the spending authority of local administration (using a concentration index - Hirschman Herfindahl Index). Interestingly, this indicator is positively related to economic growth in metropolitan areas, while the number of municipalities negatively affects economic growth. This highlights the importance of the way in which fragmentation is measured. The basic assumption is that local governments with large spending powers have greater influence to affect the economic system than local administrations with less power.

The other important caveat is the geographical scope of the analysis. Most of the literature focuses on Metropolitan areas (mainly in the USA). Stansel (2005) notes that the discrepancy with Nelson and Foster (1999) could depend on sample used. While Nelson and Foster (1999) focus on large metropolitan areas, Stansel (2005) considers metropolitan areas of all sizes, thus suggesting that the relationship between fragmentation and growth is negative in large metro areas, while turning positive in smaller ones.

The present work takes a step further in this direction, by considering the whole territory of a country and directly accounting for the way in which population is distributed over this territory. ${ }^{4}$

One of the potential problems of a fragmented administration is the tendency to have municipalities of small sizes, thus incurring into capacity gaps: for instance, limited financial capacity, limited range of skills of public administrators, etc. Several OECD publications have focused on the problems of governance gaps, implicitly suggesting that administrative fragmentation may hinder economic growth if the gaps are not adequately filled (Charbit, 2011; Charbit and Michalun, 2009).

This brief and selected overview of the literature shows that the literature on the economic impact of (horizontal) administrative fragmentation fails to take into account territorial characteristics that might be determinant for the actual impact of fragmentation. The present work fills this gap by combining measures of administrative fragmentation (absolute and population weighted) with territorial characteristics (rural index), which capture the distribution of the population over the territory (OECD 2009b; OECD 2012).

\section{Measuring fragmentation and territorial characteristics}

This section provides a discussion of alternative measures of municipal fragmentation and of the distribution of the population over the regional territory.

\footnotetext{
4. To our knowledge the only work that controls for the territorial characteristics of the jurisdiction is Dolan (1990), which considers the impact of municipal fragmentation on the cost of government (a composite indicator which accounts for several dimensions of costs in the public administration). Dolan (1990) considers the ratio between agricultural land and commercially and industrially developed land as a measure of the territorial characteristics. He finds, however, no direct impact of its rural index on government cost.
} 
Administrative fragmentation has been studied mainly in relation to US metropolitan areas. Three main measures of fragmentation are proposed: the absolute number of local councils in a given territory; the number of local councils weighted for the population; and indexes based on the functions and powers of local councils. These indicators differ in terms of information content and international comparability. The simplest way to account for administrative fragmentation is to consider the absolute number of municipalities (Cutler and Glaeser, 1997). This indicator, however, fails to take into account regional population differences, thus suffering from the fact that most populous regions tend to have more local governments than scarcely populated regions (Dolan, 1990).

The second type of indicator, therefore, is weighted by the population size of a given unit of analysis. In the current work, the municipal fragmentation index consists in the number of municipalities within a region divided by the regional population (and multiplied by 100,000). Given the number of local councils the indicator decreases with the population, implicitly assuming that the number of municipalities increases with population size. Thus accounting for the fact that bigger regions tend to have more municipalities.

Both the unweighed and the population-weighted indicators, however, treat all local councils in the same way. It does not take into account the actually fragmentation of administrative powers, that crucially depends on the functions delegated to the local level. A solution would be to create an indicator which takes into account the degree of decentralisation in each country - a fiscal dispersion measure (Dolan, 1990). The basic assumption is that local governments with large spending powers have greater influence to affect the economic system than local administrations with less power.

This indicator, however, requires a considerable amount of information about the functions actually allocated to the local level, and raises issues about data homogeneity given the differences in administrative and legal frameworks among countries.

To summarise, although the analysis would benefit from the introduction of a more refined index of (functional) fragmentation, the focus on the absolute and relative measure of fragmentation assures a higher degree of homogeneity of the dataset and allows a better international comparison.

As regards regional territorial characteristics, the analysis is conducted at the OECD territorial level 2 (TL2) which roughly corresponds to the EU NUTS2 regions for European countries, and to the administrative structure below the central government in the rest of OECD countries. For instance, for the US, the TL2 level corresponds to the US States. ${ }^{5}$

The distribution of regional population can be measured by indexes related to population density or population concentration. The OECD classify regions into three typology (namely, predominantly urban, intermediate, and predominantly rural) using a methodology based on the definition of local communities as urban or rural. In practice, the density measure is applied at the level of the local community and not for the whole region. In this framework, local communities are labelled rural if they are constituted by less than 150 inhabitants for square $\mathrm{km}$. Then aggregating up these local communities, a region is defined as predominantly rural if more than $50 \%$ of the population lives in rural communities; it is classified as intermediate if between 15 and $50 \%$ of the population lives in rural communities; and it is classified as predominantly urban if less than $15 \%$ of the population lives in rural communities (OECD, 2011). This regional typology is applied to TL3 levels, a territorial unit below the one considered in the present work.

5. For analytical purposes the OECD classifies each country's territory in TL2 and TL3 territories. The former is the territorial level immediately below the national level - it corresponds to the territory of regions in Italy and France and to the territory of the States in the USA. The TL3 territory is the way in which TL2 territories are further divided. It corresponds to the territory of province in Italy, departments in France, and counties in the USA. The territorial level does not necessary correspond to an administrative tier. For instance, in the Netherlands there is no administrative body corresponding to the TL2 territory, as below the central government there is only the provincial administration (corresponding to the TL3 definition) and the municipal level. 
In the present work, the urban/rural characteristics of OECD TL2 regions are captured by the rural index. This index is calculated starting from the classification of "local communities" in urban and rural according to the OECD regional typology framework, and then aggregating at the regional level in order to obtain the share of the population living in rural areas. Therefore, regions are not classified as rural or urban, but each region has its own degree of "rurality", thus avoiding the problem of selecting similar regions into different categories.

This indicator is correlated to the regional population density, but provides a finer measure of the distribution of population within regions. For instance, population density cannot distinguish between two regions with the same population size and surface areas, but where population is concentrated in one city or evenly spread over the territory. The rural index would be lower for the region in which the population is concentrated in few cities.

\section{Sub-national government structure in OECD countries}

Most OECD countries present a multilevel government structure. Public administration is shared between several territorial tiers (e.g., regional government, provincial government, municipal government). The number of governmental tiers within a country represent the vertical fragmentation of the public administration, which accounts for the number of government overlapping a given territory. At each government tier, however, there are more than one government body. The way in which the territory is divided at a given government tier represents the horizontal fragmentation of the public administration.

Table 1 provides an overview of both dimensions of administrative fragmentation in OECD countries. The number of municipalities (and their average size) varies a lot among OECD countries: from 67 municipalities in New Zealand, to more than 36 thousands in France. Also the vertical dimension varies from countries with only one tier like Slovenia, Estonia and Portugal, where only the municipal level is present, to countries with three sub-national tiers of government like France, Italy, and the USA.

All countries have a municipal level of government, thus justifying the use of this territorial level in our analysis. Considering horizontal fragmentation at an intermediate level of government would sensibly reduce the sample size, and would reduce international comparability, as the administrative functions and the political role of the intermediate level varies across countries much more than the municipal level does.

Table 1. SNG structure in OECD countries, 2012

\begin{tabular}{|l|l|l|l|}
\hline \multicolumn{1}{|c|}{ 2012-2013 } & Municipal level & $\begin{array}{c}\text { TL3 } \\
\text { (intermediate or } \\
\text { State/Regional } \\
\text { level }\end{array}$ & $\begin{array}{c}\text { TL2 } \\
\text { (State/Regional } \\
\text { level) }\end{array}$ \\
\hline Federations \& quasi-federations & & & \\
\hline Australia & 565 & & 8 \\
\hline Austria & 2354 & & 9 \\
\hline Belgium & 589 & 10 & 6 \\
\hline Canada & 4147 & & 13 \\
\hline Germany & 11327 & 295 & 16 \\
\hline Mexico & 2457 & & 32 \\
\hline Spain & 8116 & 52 & 17 \\
\hline Switzerland & 2408 & 26 & \\
\hline United States & 35879 & 3031 & 50 \\
\hline
\end{tabular}


Table 1. SNG structure in OECD countries, 2012 (cont.)

\begin{tabular}{|l|l|l|l|}
\hline \multicolumn{1}{|c|}{ 2012-2013 } & Municipal level & $\begin{array}{c}\text { TL3 } \\
\text { (intermediate or } \\
\text { State/Regional } \\
\text { level }\end{array}$ & $\begin{array}{c}\text { TL2 } \\
\text { (State/Regional } \\
\text { level) }\end{array}$ \\
\hline Unitary States & & & \\
\hline Chile & 345 & & 15 \\
\hline Czech Republic & 6253 & 14 & 5 \\
\hline Denmark & 98 & & \\
\hline Estonia & 226 & & 27 \\
\hline Finland & 320 & & \\
\hline France & 36700 & 101 & \\
\hline Greece & 325 & 13 & \\
\hline Hungary & 3177 & 19 & \\
\hline Iceland & 74 & & \\
\hline Ireland & 114 & & \\
\hline Israel & 254 & & \\
\hline Italy & 8092 & 110 & \\
\hline Japan & 1719 & 47 & \\
\hline Korea & 227 & 17 & \\
\hline Luxembourg & 106 & & \\
\hline Netherlands & 408 & 12 & \\
\hline New Zealand & 67 & 11 & \\
\hline Norway & 428 & 18 & \\
\hline Poland & 2479 & 380 & \\
\hline Portugal & 308 & & \\
\hline Slovak Republic & 2927 & 8 & \\
\hline Slovenia & 211 & 20 & \\
\hline Sweden & 290 & 2950 & \\
\hline Turkey & 2906 & & \\
\hline United Kingdom & 406 & & \\
\hline
\end{tabular}

Source: OECD 2013 "Sub-national governments in OECD countries: key data" (brochure), OECD, Paris.

Table 1 provides only an indication of absolute municipal fragmentation, which appears to be closely linked to the size of countries. When considering the number of municipalities weighted for the population however a different picture emerges. Figure 1 plots municipal fragmentation, constructed as the number of municipalities per 100,000 inhabitants in each country, ${ }^{6}$ against countries' population and surface area - both expressed in logarithms. It appears that the larger municipal fragmentation is achieved by countries within average population and surface area. The three countries with the highest degree of fragmentation, which are singled out in Figure 1, are Slovak Republic (54), France (56.7), and Czech Republic (59.5). Although France and Czech Republic differ in terms of population size and surface area, they are both at the top of the distribution in terms of municipal fragmentation.

6. It is worth noting that this is not the indicator used in the empirical analysis, which is constructed at the regional level. 
Figure 1. Municipal fragmentation weighted by national population size in OECD countries
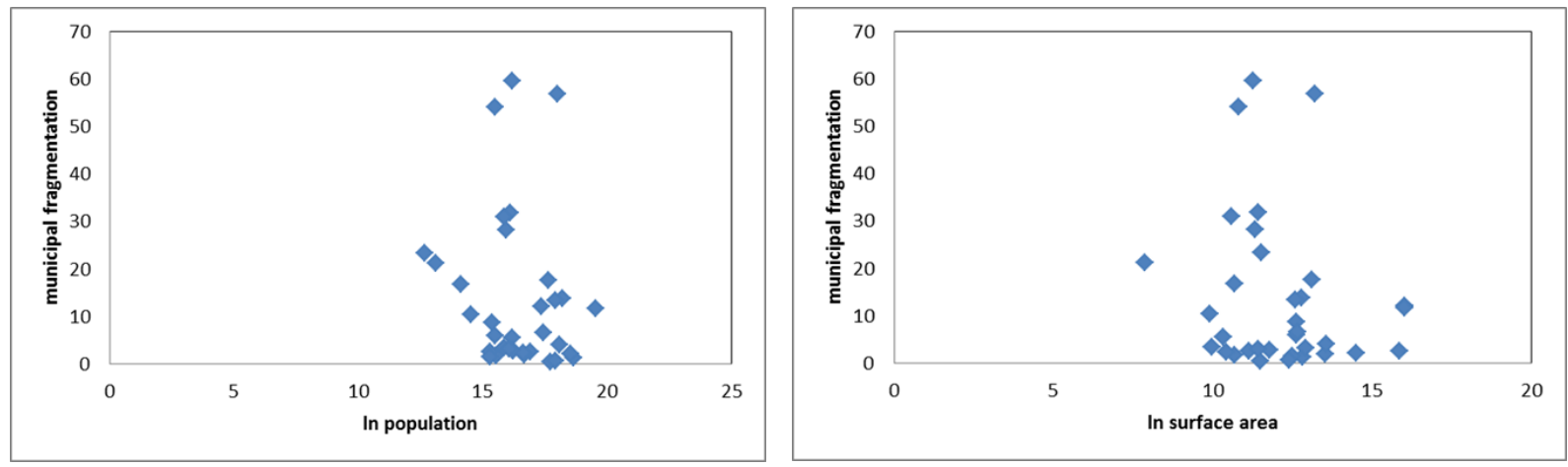

Source: Elaboration on OECD (2013) Subnational governments in OECD countries: key data

\section{Description of the data}

The empirical analysis is conducted on a cross-section of 250 TL2 regions, representing 23 OECD countries, for the period 1996 - 2011. Data are obtained from the OECD Regional Statistics Database.

The empirical model is a cross-section since many of the variables of interest are time invariant or rarely changing in time. This is the case for the fragmentation index and the rural index. For the time variant variables, the average of the variable in the relevant period has been computed. The growth of the gross regional product is calculated as the average annual growth of per capita GDP at constant PPP for the years 1996-2011. ${ }^{7}$ The rural index is constructed taking the ratio of the population living in rural areas with respect to the total population of the TL2 region. Rural areas are defined as settlements/municipalities where the density of the population is lower than 150 inhabitants per square kilometre (OECD 2011). The average value of the rural index in our sample is 0.43 , indicating that in the "average" region $43 \%$ of the population lives in rural areas. The indicator of municipal fragmentation is constructed as the ratio between the number of municipalities and the population in each TL2 region. Data about number of municipalities are obtained from countries' Census statistics. ${ }^{8}$

Several economic and demographic indicators, that are important determinant of economic performance, are taken into account as control variables. Among them of particular importance are human capital, innovation, and the political system. ${ }^{9}$ Human capital is one of the main determinants of labour productivity, contributing to GDP growth (Barro and Sala-i-Martin, 2004). The attainment level of education of the workforce is used as proxy for human capital; this indicator considers the share of the labour force with primary, secondary and tertiary education, respectively. ${ }^{10}$ The impact of

7. For the TL2 regions of Norway and Korea, the average annual growth is calculated for the period 2003-2007. For the TL2 regions of Turkey the average annual growth is calculated for the period 2004-2007.

8. Data on the number of counties in US are from the National Association of Counties, Research Division, 440 First Street, NW, Washington, DC 20001. (202) 393-6226 (as published in the webpage http://www.charlestoncounty.org/stats/bystate.htm ). For the U.S., sub-county general purpose administrative units are used as "municipalities".

9. Neither physical capital nor investments in physical capital are available at the regional level. In the model presented this element is partly capture by the level of GDP of the region which is likely to be correlated with the amount of physical capital. Thus the level of GDP can be a proxy for the level of physical capital in the absence of such regional indicator.

10. Two Canadian TL2 regions, namely Yukon and Northern Territories, have been excluded from the analysis because of lack of data on education attainment. 
innovation on regional performance is measured through the number of patents registered in each region. The level of per capita GDP in 1996 is used as proxy for the level of economic development of each region. Finally, a dummy variable accounting for the political system - Federal or Unitary - is considered, as local governments in federal countries may have more autonomy than in unitary ones.

\section{The econometric model}

The empirical analysis is conducted considering a linear econometric model where the institutional variables are interacted with the rural index. The interaction term is the crucial element for testing the hypothesis of a differentiated impact of municipal fragmentation in urban and rural regions. In particular, we expect a negative sign of the coefficient associated with municipal fragmentation, $\beta_{2}$, and a positive sign of the coefficient associated with the interaction term, $\beta_{3}$.

A set of control variable are included, as shown in the following equation

$$
g_{i}=\text { cons }+\beta_{1} \text { rur }_{i}+\beta_{2} \text { frag }_{i}+\beta_{3} \text { rurfrag }_{i}+\beta_{4} X_{i}+\varepsilon_{i}
$$

where $g_{i}$ is the annual average growth rate of per capita regional gross product in region $i$, cons is a constant term, rur is the rural index for region $i$, and frag accounts for municipal fragmentation in region $i$. Finally, $X_{i}$ is a vector of control variables, including population density, the initial level of regional per capita GDP, an indicator of patents registration, education attainment of working age population, and a dummy variable for the political system (unitary or federal).

The model is estimated using an OLS (ordinary least square) estimator and robust standard errors. The use of a panel would not add much information to the analysis as the relevant institutional variables are time invariant (or rarely changing in time). Therefore the results of the empirical analysis are driven by the comparison between regions rather than the evolution of fragmentation within each region. The analysis is conducted also with country dummies to capture regional differences that are given by countries' specific characteristics. For instance, two regions in different countries may exhibits a different growth path because of country specific macroeconomic policies.

The correlation matrix between the explanatory variables shows that there might be a potential problem of multicollineary among the education variables. In particular, Table 2 shows a strong correlation between primary and secondary education $(0.85)$. For this reason, the variable referring to secondary education is excluded from the econometric model.

Table 2. Correlation matrix

\begin{tabular}{|c|c|c|c|c|c|c|c|c|c|}
\hline & rur & frag & federal & popdens & g1996 & patents & primary & secondary & tertiary \\
\hline rur & 1 & & & & & & & & \\
\hline frag & 0.1527 & 1 & & & & & & & \\
\hline federal & 0.1705 & -0.0576 & 1 & & & & & & \\
\hline popdens & -0.4351 & -0.1237 & 0.0213 & 1 & & & & & \\
\hline g1996 & -0.1118 & -0.1085 & 0.4828 & 0.2956 & 1 & & & & \\
\hline patents & -0.1248 & -0.1943 & 0.3091 & 0.0357 & 0.4718 & 1 & & & \\
\hline primary & -0.185 & 0.0519 & -0.345 & 0.0166 & -0.1272 & -0.2655 & 1 & & \\
\hline secondary & 0.2885 & 0.0227 & 0.2135 & -0.1487 & -0.0877 & 0.0805 & -0.8473 & 1 & \\
\hline tertiary & -0.1891 & -0.1407 & 0.2185 & 0.2341 & 0.3851 & 0.309 & -0.2079 & -0.3423 & 1 \\
\hline
\end{tabular}

Interestingly, there is not much correlation between the municipal fragmentation variable and the variable representing population density (-0.12). As expected there is some correlation between the rural index and the indicator of population density $(-0.43)$, but it is not very large, thus we run the analysis both with and without controlling for population density. Furthermore, post estimation statistics for detecting multicollinearity within the regressors provide a negative result; the variance inflation factor is below the critical level for all the regressors used in the analysis (see appendix A3). 


\section{Empirical results}

The first column of Table 3 presents the results of the estimation of a model without territorial characteristics, i.e., without the rural component. The coefficient associated with municipal fragmentation is negative but not statistically significant showing as it might average the negative impact in urban regions with the null or positive impact in rural regions. A part from patents which has not a significant impact on performance, the other control variables have the expected sign: initial value of GDP is negative and significant supporting the idea of regional convergence; education has a positive and significant impact on performance, which increases with the level of education; and population density has a positive, albeit small, impact. ${ }^{11}$

Table 3. Estimation results of the impact of horizontal fragmentation on regional TL2 economic growth

\begin{tabular}{|c|c|c|c|c|c|}
\hline $\begin{array}{l}\text { dependent variable: } \\
\text { annual average growth of per capita GDP }\end{array}$ & $\begin{array}{c}(1) \\
\text { g_total } \\
(1996-2011)\end{array}$ & $\begin{array}{c}\text { (2) } \\
\text { g_total } \\
(1996-2011)\end{array}$ & $\begin{array}{c}\text { (3) } \\
\text { g_total (1996- } \\
2011)\end{array}$ & $\begin{array}{c}\text { (4) } \\
\text { g_pre crisis } \\
(1996-2007)\end{array}$ & $\begin{array}{c}(5) \\
\text { g_post crisis } \\
(2008-2011)\end{array}$ \\
\hline rural index & & $\begin{array}{c}-0.00821^{\star * *} \\
(0.00286)\end{array}$ & $\begin{array}{l}-0.00680^{* *} \\
(0.00270)\end{array}$ & $\begin{array}{l}-0.00669^{\star *} \\
(0.00323)\end{array}$ & $\begin{array}{l}-0.00710 \\
(0.00453)\end{array}$ \\
\hline municipal fragmentation & $\begin{array}{l}-1.39 \mathrm{e}-05 \\
(2.24 \mathrm{e}-05)\end{array}$ & $\begin{array}{c}-0.000112^{\star \star *} \\
(3.73 e-05)\end{array}$ & $\begin{array}{l}-4.34 e-05^{\star} \\
(2.23 e-05)\end{array}$ & $\begin{array}{l}-2.65 e-05 \\
(2.89 e-05)\end{array}$ & $\begin{array}{l}-8.99 e-05^{\star *} \\
(3.86 e-05)\end{array}$ \\
\hline Interaction: rural fragmentation & & $\begin{array}{c}0.000181^{\star * *} \\
(4.82 \mathrm{e}-05)\end{array}$ & $\begin{array}{c}0.000143^{\star * \star} \\
(2.53 e-05)\end{array}$ & $\begin{array}{l}7.74 e-05^{\star *} \\
(3.33 e-05)\end{array}$ & $\begin{array}{c}0.000322^{\text {***}} \\
(4.94 \mathrm{e}-05)\end{array}$ \\
\hline federal constitution & $\begin{array}{c}0.00165 \\
(0.00213)\end{array}$ & $\begin{array}{c}0.00177 \\
(0.00215)\end{array}$ & $\begin{array}{c}0.00379 \\
(0.00614)\end{array}$ & $\begin{array}{l}-0.00487 \\
(0.00698)\end{array}$ & $\begin{array}{l}0.0276^{* * *} \\
(0.0101)\end{array}$ \\
\hline g1996 & $\begin{array}{c}-5.71 e-07^{\star \star \star} \\
(1.88 e-07)\end{array}$ & $\begin{array}{c}-5.68 e-07^{\star \star \star} \\
(1.85 e-07)\end{array}$ & $\begin{array}{c}-5.58 \mathrm{e}-09 \\
(7.40 \mathrm{e}-08)\end{array}$ & $\begin{array}{c}-3.66 e-08 \\
(9.47 e-08)\end{array}$ & $\begin{array}{c}7.97 e-08 \\
(1.12 e-07)\end{array}$ \\
\hline patents & $\begin{array}{l}-8.49 \mathrm{e}-06 \\
(1.01 \mathrm{e}-05)\end{array}$ & $\begin{array}{l}-1.06 e-05 \\
(9.90 e-06)\end{array}$ & $\begin{array}{l}-9.29 e-06^{*} \\
(5.37 e-06)\end{array}$ & $\begin{array}{l}-7.47 e-06 \\
(6.11 e-06)\end{array}$ & $\begin{array}{l}-1.43 e-05 \\
(9.03 e-06)\end{array}$ \\
\hline primary education & $\begin{array}{c}-0.000263^{\star * *} \\
(5.84 \mathrm{e}-05)\end{array}$ & $\begin{array}{c}-0.000279^{* \star *} \\
(5.81 e-05)\end{array}$ & $\begin{array}{c}2.45 e-05 \\
(0.000158)\end{array}$ & $\begin{array}{c}2.01 e-05 \\
(0.000167)\end{array}$ & $\begin{array}{c}3.67 e-05 \\
(0.000238)\end{array}$ \\
\hline tertiary education & $\begin{array}{c}0.000235^{\star * *} \\
(8.34 \mathrm{e}-05)\end{array}$ & $\begin{array}{l}0.000195^{\star *} \\
(8.50 \mathrm{e}-05)\end{array}$ & $\begin{array}{c}0.000230 \\
(0.000221)\end{array}$ & $\begin{array}{c}0.000232 \\
(0.000262)\end{array}$ & $\begin{array}{c}0.000224 \\
(0.000300)\end{array}$ \\
\hline population density & $\begin{array}{l}1.89 e-06 * \\
(1.07 e-06)\end{array}$ & $\begin{array}{c}1.17 e-06 \\
(1.12 e-06)\end{array}$ & $\begin{array}{l}-3.91 e-07 \\
(8.60 e-07)\end{array}$ & $\begin{array}{l}-1.66 e-07 \\
(9.83 e-07)\end{array}$ & $\begin{array}{l}-1.01 e-06 \\
(9.22 e-07)\end{array}$ \\
\hline Constant & $\begin{array}{l}0.0319^{* * *} \\
(0.00368)\end{array}$ & $\begin{array}{l}0.0374^{* * *} \\
(0.00402)\end{array}$ & $\begin{array}{c}0.0129 \\
(0.0143)\end{array}$ & $\begin{array}{c}0.0240 \\
(0.0161)\end{array}$ & $\begin{array}{l}-0.0175 \\
(0.0203)\end{array}$ \\
\hline country dummies & No & No & Yes & Yes & Yes \\
\hline Observations & 250 & 250 & 250 & 250 & 250 \\
\hline R-squared & 0.301 & 0.332 & 0.738 & 0.624 & 0.807 \\
\hline
\end{tabular}

Robust standard errors in parentheses

${ }^{* \star *} p<0.01,{ }^{\star *} p<0.05,{ }^{*} p<0.1$

The inclusion of the rural index confirms the hypothesis of a differentiated impact of fragmentation. The second column of Table 3 shows that the coefficients associated with municipal fragmentation and the interaction term are statistically significant at the $1 \%$ level. The sign of the

11. The same results are obtained when removing population density from the regression, in particular the coefficient associated with municipal fragmentation is still negative but not statistically significant. 
coefficients is as expected, with the impact of fragmentation being negative but decreasing with the rural index (because of the positive coefficient of the interaction term). The negative and statistically significant coefficient associated with the rural index, confirms that rural region tend to grow less than urban ones. Similar results are obtained if we substitute the dependent variable with the value added (VA) per worker. This shows that one of the main channels of the impact of fragmentation is labour productivity. ${ }^{12}$

The empirical analysis is replicated with the introduction of country dummies that capture the influence of country specific characteristics on regional economic performance. Column 3 shows that the main results are still valid, in particular the coefficient of the interaction term is of similar magnitude and still significant at the $1 \%$ level.

The effect of municipal fragmentation on regional performance is therefore given by the direct effect captured by $\beta_{2}$, and the coefficient of the interaction term $\beta_{3}$. According to the estimation in column (3), where country dummies are taken into account, the marginal impact of fragmentation on GDP growth given by the following expression

$$
\frac{\partial g}{\partial f r a g}=-(0.000043)+(0.000143) r u r
$$

which is negative for small values of the rural index. Indeed, if the region is characterised by a rural index equal to 0, i.e., all the population lives in urban areas, then the marginal impact of fragmentation is -0.000043 . The impact turns positive for regions in which more than $30 \%$ of the population lives in rural areas, which corresponds to $30 \%$ of the regions in the sample and $76 \%$ of the population. This implies that a $10 \%$ reduction in the index of fragmentation produces a $0.8 \%$ increase in the annual per capita growth rate.

The empirical results are robust to the introduction of country dummies, to the measure of GDP in terms of labour productivity (VA per worker), and to an alternative measure of fragmentation: the absolute number of municipalities. The latter is an important robustness check, because our analysis seems not to be affected by the volatility observed in previous works. For instance, Dolan (1990) reports that the impact of fragmentation drastically changes when considering absolute fragmentation instead of per capita fragmentation. This is another indication of the importance of accounting for the distribution of the population within the territory in order to identify the impact of horizontal fragmentation. Moreover, the robustness of our results with respect to changes in the indicator used to measure fragmentation can be taken as a further proof of the importance of including a territorial indicator (e.g., rural index, population density, population concentration, etc.) in the analysis.

The analysis suggests that the reduction of fragmentation is beneficial only in urban regions. This is due to the different distribution of the population over the territory. In urban areas the population is concentrated, so that the economic interactions are likely to spill over the municipal administrative borders, thus benefitting from a process of amalgamation more than rural areas where the population is spread over a vast territory and interactions are weaker. For instance, municipal fragmentation can damage transportation policy if citizens commute over different municipal boarders, so that an integrated plan would serve citizens better than several unconnected policies. By contrast, political representation and access to politicians is more a concern for people spread over a vast territory than within a metropolitan area.

A graphical representation of the empirical results is obtained by running a post regression diagnosis. Figure 2 shows three different component-plus-residual plots of fragmentation for the whole sample, a sub-sample of urban and rural regions, respectively.

12. The work is conducted using GDP per capita because data are available for more years and more regions than data on value added per worker. 
Figure 2. Impact of fragmentation on GDP - post regression diagnostic

Full sample

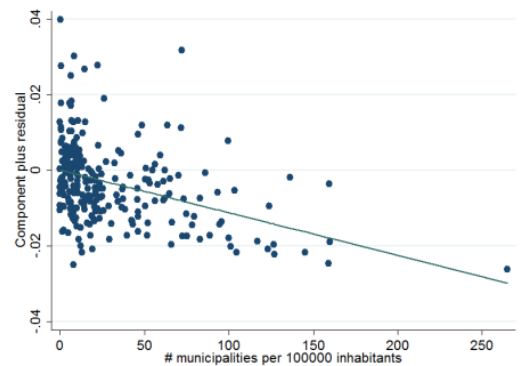

Urban regions (rur<0.5)

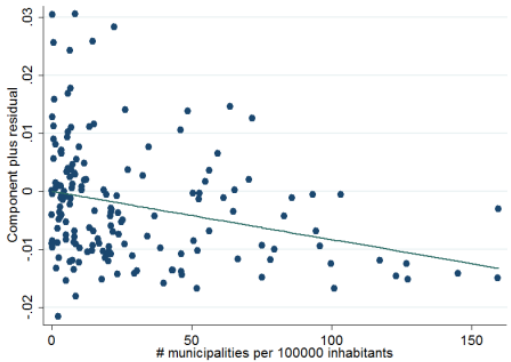

Rural regions (rur>0.5)

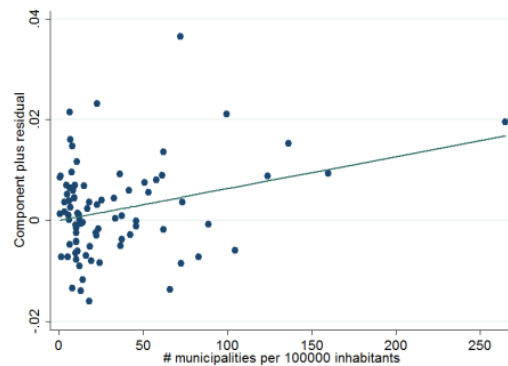

The three plots in Figure 2 show that the negative impact of municipal fragmentation is actually driven by the regions in our sample with a rural index lower than 0.5 (166 regions). The sub-sample of regions with a rural index greater than 0.5 (84 regions) shows actually a positive relationship, although the relationship is really driven by a few regions.

Figure 4 plots the average impact of horizontal fragmentation (computed using the estimated marginal impact) on TL2 regions with respect to their population density. As population density increases the impact becomes negative. It is worth noting that this relationship is not obtained if we consider only population size, meaning that the estimated impact of the administrative reform does not depend on the population size of a region but on the concentration (density) of the population in rural areas (rural index). In the appendix, the same relationship is computed and represented separately for each country in our sample.

Figure 3. Estimated effect of institutional fragmentation on annual per-capita GDP growth, in TL2 regions (with country effects)

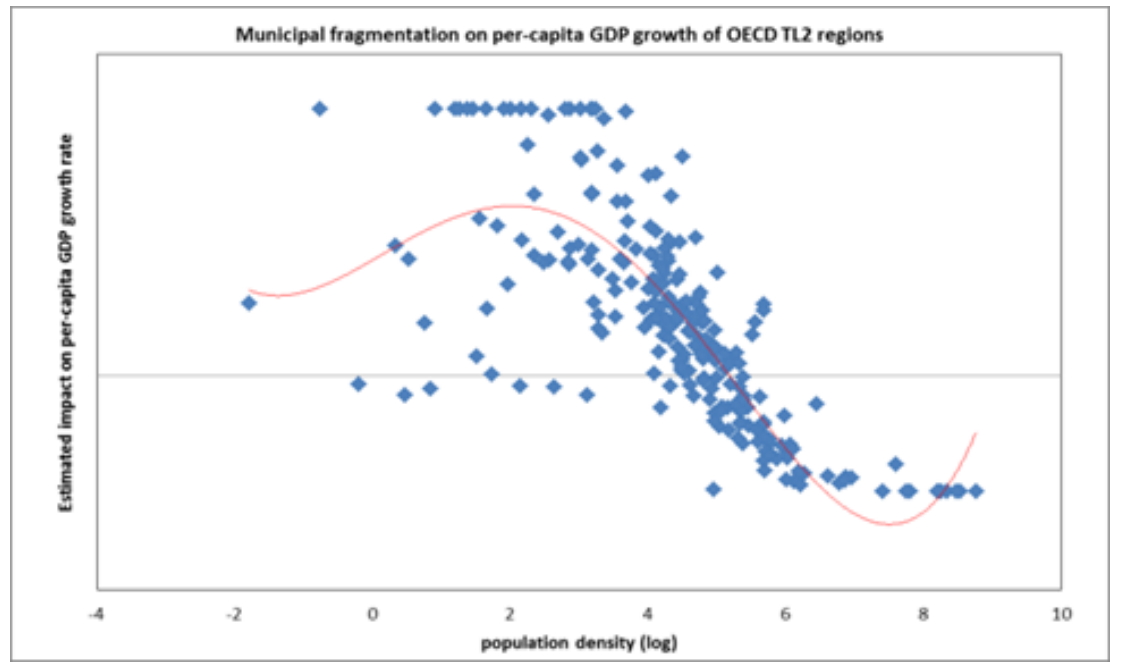

The analysis shows that in few countries a reduction of municipal fragmentation is likely to have a homogeneous effect, either positive or negative (Figure 4). In Belgium, and Luxembourg the positive effect is driven by the high density of population over the whole territory, which in geographical terms (especially for Luxembourg) is quite small. For the UK, the result is most probably driven by the partition of the territory in large TL2 statistical units, so that most of the population lives in the urban centres within these regions. In most of the countries the effect is estimated to be positive in some regions and null or negative in others. 


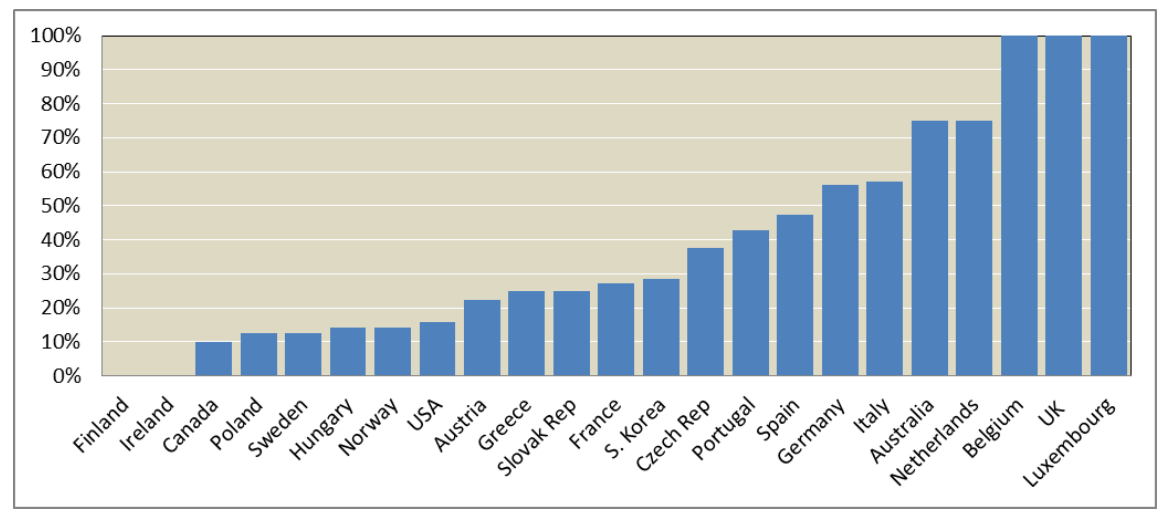

The analysis covers the 15 year period between 1996 and 2011. The most relevant event occurring in this period is the financial crisis in 2007 and subsequent "great recession". In order to account for this change in the economic environment, the analysis is replicated on two sub-periods: the pre-crisis period, from 1996 to 2007; and the post-crisis period 2008-2011. The results of the analysis performed on these two sub-samples are consistent with the analysis conducted over the whole period, the rural index and the indicator of administrative fragmentation display a negative impact on GDP growth, while the interaction term is positive. The difference is on the magnitude of the estimated coefficient and its statistical significance. It appears that the negative impact of the rural index is statistically significant only in the pre-crisis period, while the negative impact of fragmentation is statistically significant only in the post-crisis period. This is consistent with the view that the financial crisis struck harder in urban and metropolitan areas. Interestingly, fragmentation seems to emerge as a significant problem only during the crisis. The large magnitude and statistical significance of the interaction term in the post-crisis period reinforces the message that municipal fragmentation is a problem in mainly urban regions and seems to be amplified in periods of economic recession or stagnation.

To summarise, the empirical analysis support the hypothesis that municipal fragmentation hinders regional economic growth in urban areas, with an increasing impact given by the inverse of the rural index. Results are robust to different specifications of the model (inclusion of country dummies) and the use of different indicators (VA per worker). The fact that results are robust to the inclusion of fragmentation both in absolute terms and relative to population highlights the importance of including a territorial dimension in the analysis. In terms of policy, the analysis provides empirical support to a place-based approach to territorial reforms. For instance, a policy aiming at reducing the number of municipalities should focus more on urban than rural areas. In other words, it might be efficient in terms of economic development to reduce the number of municipalities in urban areas, while keeping - even small - municipalities in rural regions.

\section{Concluding remarks}

The analysis provides empirical evidence for a differentiated impact of municipal fragmentation in urban vis à vis rural regions. In particular, fragmentation hinders GDP per capita growth the more urban is the region. In fact, in regions where most of the population lives in rural areas municipal fragmentation appears to have no impact or enhancing growth. For OECD TL2 regions with more than $30 \%$ of people living in rural areas, fragmentation is actually positively correlated to economic growth.

The results of the empirical analysis suggest that reforms of the administrative structure of a country should take into account regional territorial differences, advocating for a place-based approach to institutional reform. The reduction of municipal fragmentation may lead to better economic performance only in regions where most of the population lives in urban areas (e.g., regions that contain metropolitan areas). 
The policy implications of the analysis are twofold. Firstly, reducing municipal fragmentation may have a heterogeneous impact within the country, thus raising concern for one-size-fits-all policies of municipal agglomeration in favour of a place-based approach to institutional reform. For instance, the principle guiding municipal amalgamation should not be the average municipal size at the country level, but it should be weighted for the rural/urban characteristics of each region. Secondly, the analysis suggests that processes of agglomeration of people should be accompanied by a consistent amalgamation of the local administration, otherwise representing an obstacle to the full realisation of agglomeration economies.

The present work represents a first towards a better understanding of the relationship between sub-national administrative structure and economic performance by considering regional territorial characteristics. Further analysis should be made in order to account for the actual functions that are managed at the local level and the role played by vertical fragmentation (i.e., the presence of a multilevel government structure) on the economic performance of regions. 


\section{APPENDIX}

\section{A1. Impact of municipal fragmentation in OECD countries}

The analysis conducted in the previous sections provides empirical evidence to a differentiated impact of municipal fragmentation in urban and rural regions. Table 4 represents the marginal effect of fragmentation (as estimated in our model) on per-capita GDP growth, where regions are grouped by countries. The marginal impact is plotted against regional population density.

Table 4. Impact of fragmentation on per-capita GDP growth, by country

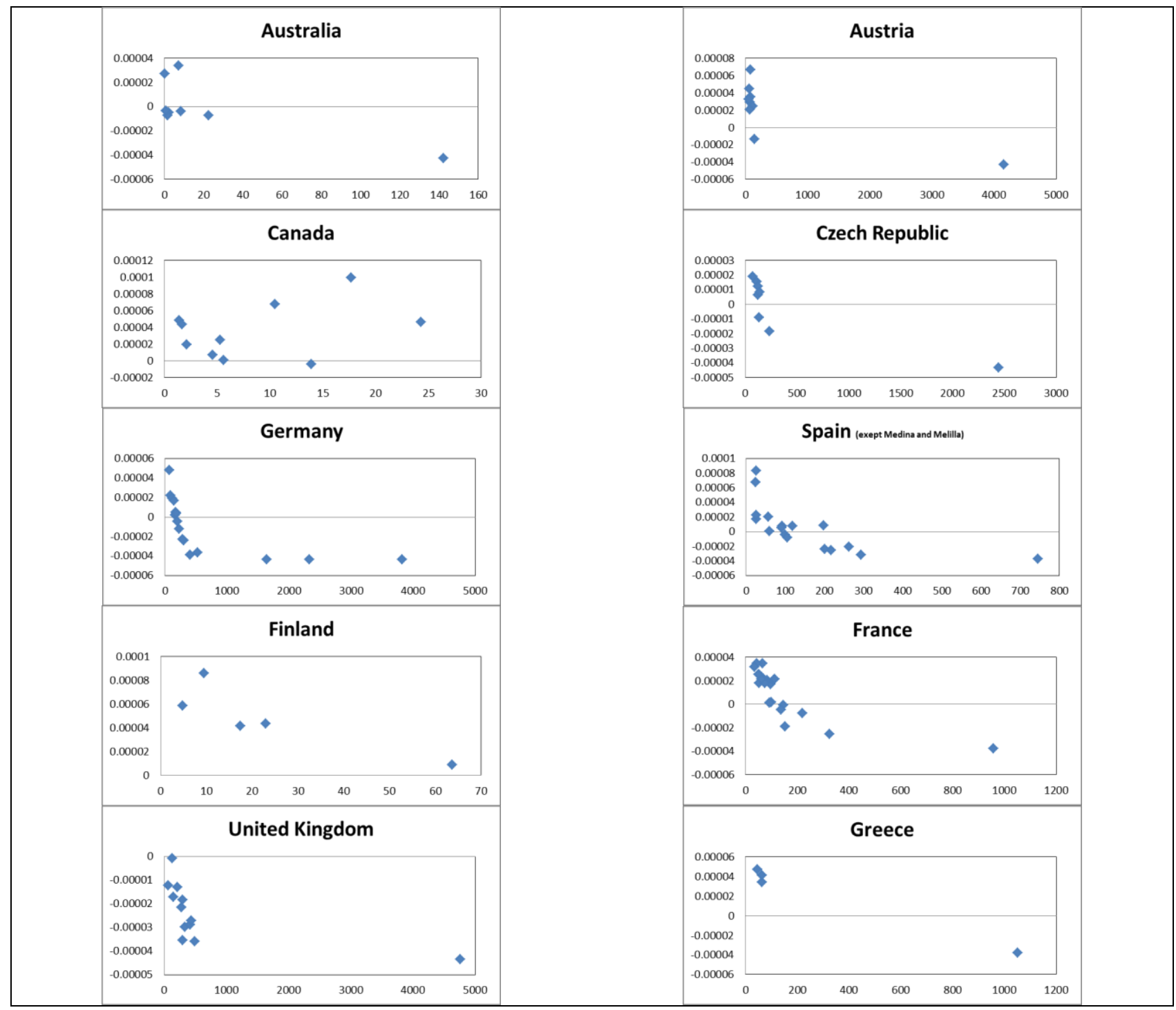


Table 4. Impact of fragmentation on per-capita GDP growth, by country (cont.)

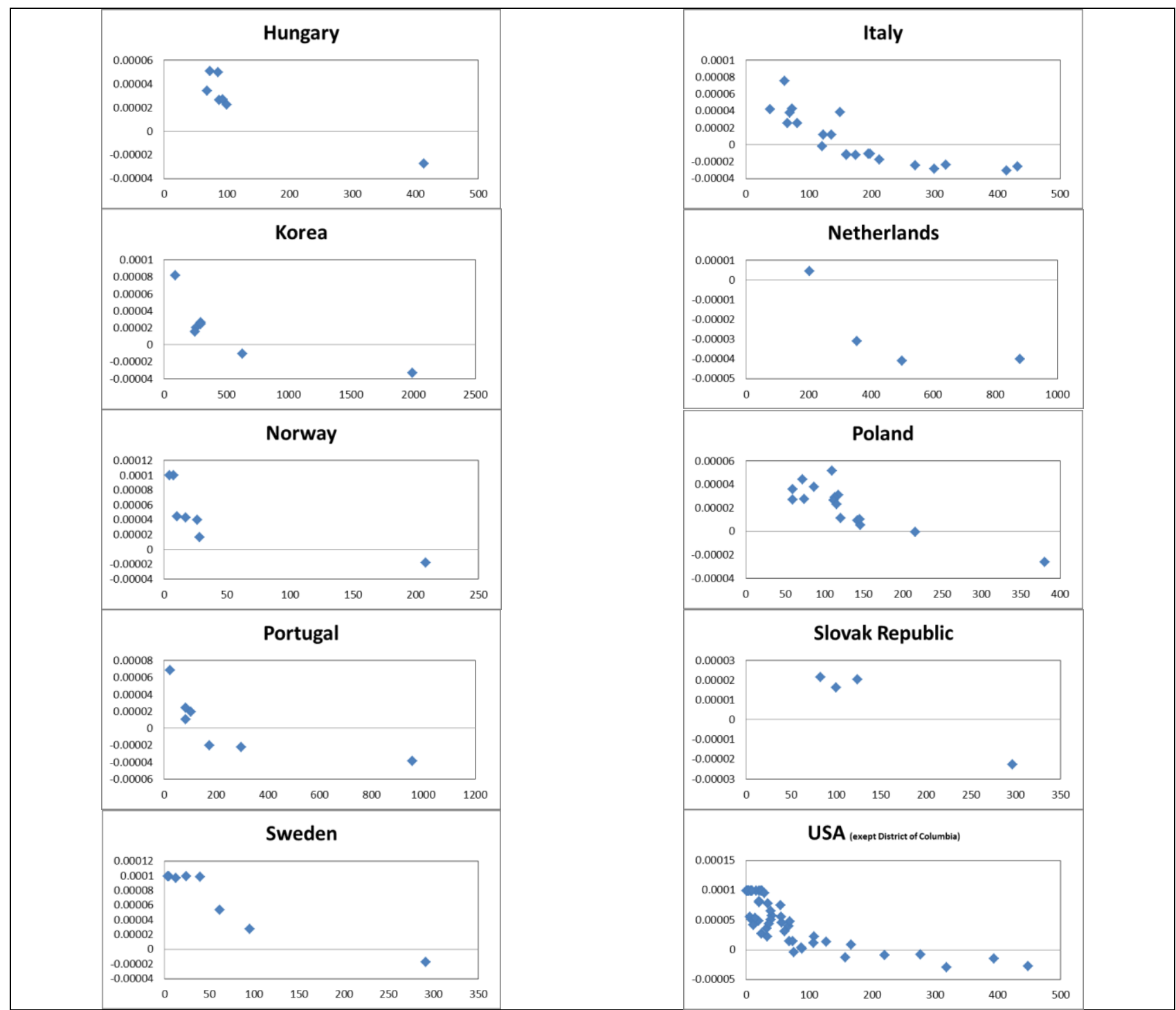

Note: data on Belgium, Luxembourg, and Ireland are not displayed as a plot, because they consist of less than four observations.

The plots show that within countries the marginal impact of fragmentation is positive for some regions (less densely populated) and negative for other. In most countries it is difficult to predict the overall effect of a reform that reduces (or increases) municipal fragmentation.

\section{A2. Administrative territorial reforms may result in asymmetries between urban and rural areas}

The last ten years have been characterised by an intense activity of reform of the sub-national administrative structure in many OECD countries (see Table 1). In some cases, the process has received a further stimulus by the economic crisis which forced many governments to pursue a path of fiscal consolidation. Territorial administrative reforms, especially the reduction of administrative bodies, could lead to a more efficient use of resources and thus contribute to countries' financial stability. 
Table 5. Territorial administrative reforms in a selection of OECD countries

\begin{tabular}{|c|c|c|c|}
\hline $\begin{array}{l}\text { Country, } \\
\text { year }\end{array}$ & $\begin{array}{c}\text { Municipal } \\
\text { fragmentation }\end{array}$ & Multilevel structure & Note \\
\hline $\begin{array}{l}\text { Latvia, } \\
2009\end{array}$ & $\begin{array}{l}\text { Reduction of the } \\
\text { number of } \\
\text { municipalities from } \\
527 \text { to } 119\end{array}$ & $\begin{array}{l}\text { Abolished the intermediated level of } \\
\text { government ( } 26 \text { districts), leaving } \\
\text { only one level of sub-national } \\
\text { government (the municipal level) }\end{array}$ & $\begin{array}{l}\text { The reform did not distinguish } \\
\text { between urban and rural areas. }\end{array}$ \\
\hline $\begin{array}{l}\text { Germany, } \\
2006- \\
2011\end{array}$ & $\begin{array}{l}\text { Trend of mergers } \\
\text { between } \\
\text { municipalities } \\
\text { leading to a decline } \\
\text { from } 16,216 \text { in } \\
1990 \text { to } 11,327 \\
\text { municipalities in } \\
2012 \text { (a drop of } \\
30 \% \text { ) }\end{array}$ & & $\begin{array}{l}\text { The trend of mergers affected some } \\
\text { Federal States more than others; } \\
\text { for instance, in } 2011 \text { the number of } \\
\text { municipalities in Saxony-Anhalt was } \\
\text { reduced from } 840 \text { to } 219 \text { (where } \\
44 \% \text { of the population lives in rural } \\
\text { areas) }\end{array}$ \\
\hline Italy, 2014 & $\begin{array}{l}\text { No mergers of } \\
\text { municipalities, but } \\
\text { inter-municipal co- } \\
\text { operation is } \\
\text { encouraged for } \\
\text { municipalities with } \\
\text { less than } 5,000 \\
\text { inhabitants }\end{array}$ & $\begin{array}{l}\text { Transformation of the intermediate } \\
\text { level of government (provinces) into } \\
\text { an assembly of mayors. Creation of } \\
\text { ten metropolitan governance bodies } \\
\text { (città metropolitana) for the } \\
\text { administration of large cities }\end{array}$ & $\begin{array}{l}\text { Some provinces are transformed in } \\
\text { metropolitan bodies while other in } \\
\text { assembly of majors. This may } \\
\text { create an asymmetry in terms of } \\
\text { functions and competences. }\end{array}$ \\
\hline $\begin{array}{l}\text { France, } \\
2014\end{array}$ & & $\begin{array}{l}\text { In December } 2013 \text { was passed a } \\
\text { law creating new governance } \\
\text { structure for the top three } \\
\text { metropolitan areas (Paris, Lyon, and } \\
\text { Aix-Marseille) as well as for } 11 \text { other } \\
\text { urban areas of more than } 400,000 \\
\text { inhabitants on a voluntary basis. } \\
\text { According to a draft law the } \\
\text { competences of the intermediate } \\
\text { level, départements, may be } \\
\text { modified, and merges among them } \\
\text { and among regions considered. } \\
\text { The reform of the Regional level of } \\
\text { government was adopted in } 2014\end{array}$ & $\begin{array}{l}\text { The reform implicitly introduces an } \\
\text { asymmetric governance structure } \\
\text { between big urban centres and rural } \\
\text { regions }\end{array}$ \\
\hline $\begin{array}{l}\text { Greece, } \\
2010-11\end{array}$ & $\begin{array}{l}\text { In January } 2011 \text {, } \\
\text { the number of } \\
\text { municipalities } \\
\text { decreased from } \\
1,033 \text { to } 325 \text { (a } \\
\text { three-fold drop) }\end{array}$ & $\begin{array}{l}\text { The } 54 \text { departments were replaced } \\
\text { by } 13 \text { democratically elected regions, } \\
\text { including two metropolitan regions } \\
\text { (Attica and Thessaloniki) }\end{array}$ & $\begin{array}{l}\text { The so-called Kallikratis reform, } \\
\text { adopted as part of the } 3852 / 2010 \\
\text { law and operational since } 1 \text { January } \\
2011 \text {, is both a territorial reform and } \\
\text { institutional reform. }\end{array}$ \\
\hline $\begin{array}{l}\text { Denmark, } \\
2007\end{array}$ & $\begin{array}{l}\text { As a result of the } \\
\text { territorial } \\
\text { administrative } \\
\text { reform the number } \\
\text { of municipalities } \\
\text { dropped from } 271 \\
\text { to } 98, \text { with an } \\
\text { average population } \\
\text { of } 55,000 \\
\text { inhabitants. }\end{array}$ & $\begin{array}{l}\text { Replacement of } 13 \text { counties by } 5 \\
\text { newly created regions (at the NUTS } 2 \\
\text { level) }\end{array}$ & $\begin{array}{l}\text { The reform included a new } \\
\text { distribution of tasks between levels } \\
\text { of government, and a new financing } \\
\text { and equalisation system. The } \\
\text { merger of municipalities was } \\
\text { achieved by imposing a limit of } \\
20,000 \text { inhabitants for any } \\
\text { municipality. }\end{array}$ \\
\hline
\end{tabular}

Source: Various sources compiled by OECD; Dexia (2012) Sub-national public finance in the European Union, Dexia editions, Paris; Nam, Chang-woon, "Subnational Government System in the EU and Its Recent Reforms", CESifo DICE Report 11 (4), 2013. 
Table 5 shows a wide range of reforms implemented by OECD countries. Although they are country specific and differ in many aspects, one common feature of the reform addressing the municipal structure is the nationwide scope of the reform, with no distinction between urban and rural territories. As documented by the empirical analysis, the same reform may lead to different results in different countries, because of a different distribution of the regional population.

\section{A3. Post-estimation test of multicollinearity}

The set of dependent variables employed in the analysis should be linearly independent; otherwise the results of the analysis are highly unstable. In fact, the presence of regressors that are linear combination of another regressor poses a problem of multicollinearity. In order to test for multicollinearity it is possible to use the variance inflation factors (VIFs). This indicator provides a measure of the degree of collinearity among dependent variables. As a rule of thumb a threshold of 0.1 for the inverted VIF is usually used judge the presence of multicollineairty. In our case, all dependent variables display a factor higher than 0.1 , showing no sign of multicollinearity.

Table 6. Post estimation test of multicollinearity

\begin{tabular}{lll}
\hline Variable & VIF & 1/VIF \\
\hline rurfrag & 5.1 & 0.196243 \\
frag & 4.55 & 0.219779 \\
g1996 & 1.85 & 0.541459 \\
rur & 1.83 & 0.547912 \\
federal & 1.54 & 0.650064 \\
patents & 1.49 & 0.670392 \\
popdens & 1.42 & 0.706543 \\
tertiary & 1.3 & 0.767956 \\
primary & 1.27 & 0.788658 \\
\hline \multicolumn{2}{l}{ Mean VIF } & 2.26 \\
\hline \hline
\end{tabular}




\section{REFERENCES}

Acemoglu, D and J. A. Robinson (2006) Economic Origins of Dictatorship and Democracy, Cambridge University Press.

Ahrend, R., Farchy E., Kaplanis I. and A. Lembcke (2014), What Makes Cities More Productive? Evidence on the Role of Urban Governance from Five OECD Countries, OECD Regional Development Working Papers, No. 2014/05, OECD Publishing, http://dx.doi.org/10.1787/5jz432cf2d8p-en.

Akai, N. and M. Sakata (2002) Fiscal decentralization contributes to economic growth: evidence from state-level cross-section data for the United States, Journal of Urban Economics, 53, pp. 93108.

Barro, R. and X. Sala-i-Martin (2004) Economic Growth, MIT Press, second edition.

Brennan, D. and J. Buchanan (1980) The power to tax: analytical foundations of a fiscal constitution. Cambridge University Press, Cambridge.

Charbit, C. (2011), "Governance of Public Policies in Decentralised Contexts: The Multi-level Approach", OECD Regional Development Working Papers, No. 2011/04, OECD Publishing, http://dx.doi.org/10.1787/5kg883pkxkhc-en.

Charbit, C. and M. Michalun (2009), "Mind the Gaps: Managing Mutual Dependence in Relations among Levels of Government", OECD Working Papers on Public Governance, No. 14, OECD Publishing, http://dx.doi.org/10.1787/221253707200.

Davoodi, H. and H. Zou (1998) Fiscal decentralization and economic growth: a cross country study, Journal of Urban Economics, 43, pp. 244-257.

Dollery and Robotti (eds) (2008) The theory and practice of local government reform. Edward Elgar.

Grassmueck G. and M. Shields (2010) "Does government fragmentation enhance or hinder metropolitan economic growth?" in Papers in Regional Science, 89(3), pp. 641-657.

Hirschman, A. (1970) Exit, Voice, and Loyalty: Responses to Decline in Firms, Organizations, and States. Cambridge, MA: Harvard University Press.

Iimi, A. (2005) Decentralization and economic growth revisited: an empirical note. Journal of Urban Economics, 57, pp. 449-461.

Lars, P. F, H. Zimmermann and T. Döring (2004) Federalism, Decentralization, and Economic Growth, Philipps-Universität Marburg Working Paper No. 30/2004, Marburg.

Lin, J.Y. and Z. Liu (2000) Fiscal decentralization and economic growth in China, Economic Development and Cultural Change, 49, pp. 1-21.

Nelson, A. and K. Foster (1999) "Metropolitan governance structure and income growth" in Journal of Urban Affairs, 21(3), pp. 309-324. 
North, D (1990) Institutions, Institutional Change and Economic Performance, Cambridge University Press.

OECD (2012), Promoting Growth in All Regions, OECD Publishing, Paris, http://dx.doi.org/10.1787/9789264174634-en.

OECD (2011) "OECD regional typology" (methodology document), Directorate for Public Governance and Territorial Development, Paris, http://www.oecd.org/gov/regionalpolicy/OECD regional typology Nov2012.pdf.

OECD (2010a), Regional Development Policies in OECD Countries, OECD Publishing, Paris, http://dx.doi.org/10.1787/9789264087255-en.

OECD (2010b), Strategies to Improve Rural Service Delivery, OECD Publishing, Paris, http://dx.doi.org/10.1787/9789264083967-en.

OECD (2009b), How Regions Grow: Trends and Analysis, OECD Publishing, Paris, http://dx.doi.org/10.1787/9789264039469-en.

Paytas, J. (2001) Does governance matter? The dynamics of metropolitan governance and competitiveness. Pittsburg, PA: Carnegie Mellon Center for Economic Development.

Randall E. and T. Gronberg (1990) "Structure, conduct and performance in the local public sector" in National Tax Journal.

Rodriguez-Posé, A. and R. Ezcurra (2010) Is fiscal decentralization harmful for economic growth? Evidence from the OECD countries, Journal of Economic Geography, 11, pp. 619-643.

Stansel D. (2005) "local decentralisation and local economic growth: a cross-sectional examination of US metropolitan areas" in Journal of Urban Economics.

Thornton, J. (2007) Fiscal decentralization and economic growth reconsidered, Journal of Urban Economics, 61, pp. 64-70.

Tiebout, C. M. (1956) "A pure theory of local expenditure" in Journal of Political Economy, 64(5), pp. 416-424.

Treisman, D. (2006) "Fiscal Decentralization, Governance, and Economic Performance: a Reconsideration" in Economics \& Politics, 18 (2), pp. 219 - 235.

Treisman, D. (2002a) “Decentralization and the Quality of Government”. UCLA. Mimeo.

Treisman D. (2002b) “Defining and Measuring Decentralisation: A global perspective." UCLA. Mimeo.

Williamson, O. E. (2010) Transaction cost economics: the natural progression, American Economic Review, 100, pp. 673-690.

Williamson, O. E. (1975) Markets and hierarchies: Analysis and antitrust implications, New York: Free Press.

Zhang, T. and H. Zou (1998) Fiscal decentralization, public spending and economic growth in China, Journal of Public Economics, 67, pp. 221-240. 